\title{
Archaeological dating of colluvial and lacustrine deposits in a GIS environment investigating the multi-period site Gortz 1 on Oberer Beetzsee, Brandenburg
}

\author{
Janko Reichel ${ }^{1}$, Sophie F. Heisig ${ }^{2}$, Thomas Schenk ${ }^{1}$, and Thomas Schatz ${ }^{3}$ \\ ${ }^{1}$ Landscape Archaeology, University of Applied Sciences, Berlin, Germany \\ ${ }^{2}$ Prehistoric Archaeology, Freie Universität, Berlin, Germany \\ ${ }^{3}$ Soil Science, Berlin, Germany
}

Correspondence: Janko Reichel (janko-reichel@gmx.net)

Relevant dates: $\quad$ Received: 22 February 2019 - Revised: 11 May 2019 - Accepted: 26 May 2019 Published: 18 July 2019

How to cite:

Reichel, J., Heisig, S. F., Schenk, T., and Schatz, T.: Archaeological dating of colluvial and lacustrine deposits in a GIS environment investigating the multi-period site Gortz 1 on Oberer Beetzsee, Brandenburg, E\&G Quaternary Sci. J., 68, 107-117, https://doi.org/10.5194/egqsj-68-107-2019, 2019.

Abstract:

From the mid-14th century CE onwards, extensive soil erosion, caused by intensive agricultural practices, has led to the destruction of landscape structures in Central Europe. In 2016, the University of Applied Sciences in Berlin investigated the colluvial deposits at the site of Gortz in western Brandenburg (Germany), which had accumulated on the lower slopes and were caused by the processes just mentioned.

The mapping of each individual archaeological find made it possible to project all finds onto one profile running along the slope. Transformation of the finds' coordinates from profile view to plan view enabled the visualization in a Geographical Information System (GIS). The combination of adjacent strata into larger units using a pedological and sedimentological approach enabled an improved dating of colluvial deposits. In addition, the method facilitated the dating of historical water levels in the Beetzsee chain of lakes, which are part of the Havel river system.

As a result, it could be demonstrated that substantial anthropogenic activity, such as clay quarrying and bank straightening, took place during the Late Slavic Period. An interlocking horizon of colluvial and lacustrine deposits indicates that the water level of the lake Oberer Beetzsee rose from a value under $29.4 \mathrm{~m}$ above sea level (a.s.l.) in the 11 th/12th century CE to approximately $29.8 \mathrm{~m}$ a.s.l. in the 13th century CE. However, isolated flooding events during the 13th century CE can be recorded up to a height of $30.5 \mathrm{~m}$ a.s.l. A modern colluvial deposit of $1 \mathrm{~m}$ in thickness indicates an acute endangerment of the archaeological site by modern agriculture.

Kurzfassung: $\quad$ Flächenhafte Bodenerosion, ausgelöst durch intensive landwirtschaftliche Nutzung, führte ab Mitte des 14. Jahrhunderts u.Z. zur Zerstörung von Landschaftsstrukturen und in Mitteleuropa. Kolluvien, welche durch diese Prozesse entstanden und am Unterhang akkumulierten, wurden auf dem Fundplatz Gortz (westliches Brandenburg, Deutschland) durch die Hochschule für Technik und Wirtschaft Berlin im Jahr 2016 untersucht. 
Konsequente Einzelfundeinmessung ermöglichte die Projizierung aller Funde auf eines der längs zum Hang verlaufenden Profile. Koordinatentransformation der Funde von der Profilansicht in die Draufsicht, ermöglichte die Visualisierung in einem GIS. Die Zusammenfassung benachbarter Schichten auf Basis der bodenkundlich-sedimentologischen Ansprache ermöglichte eine verbesserte Datierung der Kolluvien. Zusätzlich ermöglichte diese Methode die Datierung historischer Pegelstände der Beetzseekette, eines Teils des Flusssystems der Havel.

Im Ergebnis ließen sich für die spätslawische Zeit starke anthropogene Aktivitäten wie Mergelabbau und eine Uferbegradigung nachweisen. Über einen Verzahnungshorizont limnischer und kolluvialer Sedimente. ließ sich ein Pegelanstieg des Oberen Beetzsees von einem Wert unterhalb von $29.4 \mathrm{~m}$ Normalhöhennull (NHN) im 11./12. Jahrhundert u.Z. auf etwa $29.8 \mathrm{~m}$ NHN im 13. Jahrhundert u.Z. feststellen. Es lassen sich für das 13. Jahrhundert u.Z. jedoch auch vereinzelte Überschwemmungsereignisse bis in eine Höhe von $30.5 \mathrm{~m}$ NHN fassen.

Ein modernes Kolluvium von einem Meter Mächtigkeit zeigt die akute Gefährdung des Bodendenkmals durch die moderne Landwirtschaft.

\section{Introduction and objectives}

The combination of archaeological and soilsedimentological investigations into erosion processes at archaeological sites enables reliable conclusions to be made about historical settlement phases and their paleoenvironmental context. At the same time, erosion can be used to draw conclusions about the sub-recent to recent destruction of archaeological sites. In the best case, this can be used to derive scientific recommendations for the agricultural use of the land.

The Gortz 1 site, which is the focus of this study, has been subject to intensive agricultural use since the middle of the 20th century and is therefore subject to extensive soil erosion. Systematic field walking on sections of the site resulted in the collection of 7600 surface finds from 2.6 ha (Schenk, 2018). This accumulation can be seen as a clear indicator of the destruction of associated archaeological features. However, erosion processes are not just the result of modern agriculture alone; rather, they are associated with many anthropogenic interventions in existing landscape structures since the Neolithic Age. The consequence of soil erosion is a shift of the topsoil from the upper slopes to the lower slopes and the foot of the slope and beyond. These relocated soils are referred to as colluvia. Almost every anthropogenic activity phase leads to the formation of a colluvial deposit. It often contains material remains from when the deposit was first laid down. The colluvial deposit thus represents a sort of archive of the activity phase, which can be dated archaeologically via the associated ceramics. The thickness of the colluvia gives an indication of the intensity of the activity phase. If very little or no ceramics can be found for an epoch, this is an indication of an anthropogenic resting phase, i.e. a period in which no ceramics were used or relocated which could indicate less intensive human activity. The terms activ- ity and resting phase are used according to the definition of Bork (Bork et al., 1998).

For the investigation presented here, the shore location of the archaeological site plays a significant role. The site is connected to the Havel river system via the Beetzsee chain of lakes. Therefore, dating of lacustrine deposits enables us to draw conclusions about the former spatial extension of water bodies in the wider landscape. These conclusions extend far beyond the boundaries of the site.

The aim of the study is to determine the former erosion history, paleo-environmental context and sub-recent to recent history of the destruction of this archaeological site. The research presented in this paper focuses on the following objectives:

1. dating of colluvial and lacustrine deposits,

2. categorization of phases of anthropogenic activity and resting,

3. investigation of historical water levels in the Beetzsee chain of lakes and the associated landscape development, and

4. assessment of the present-day risk to the archaeological site.

\section{Research area}

Located within the wider Havel river system, the archaeological site of Gortz 1 lies on the banks of a lake which is part of the Beetzsee chain of lakes. The lake chain was formed during the Brandenburg glacial stage (24-17 ka BP) in the Weichselian High Glacial, as a subglacial drainage channel (Lippstreu and Hermsdorf, 2010). The maximal extent and intermediate positions of the ice sheet were located south of or probably through this channel during this period (Stackebrandt and Lippstreu, 2010). The Beetzsee chain of lakes ex- 


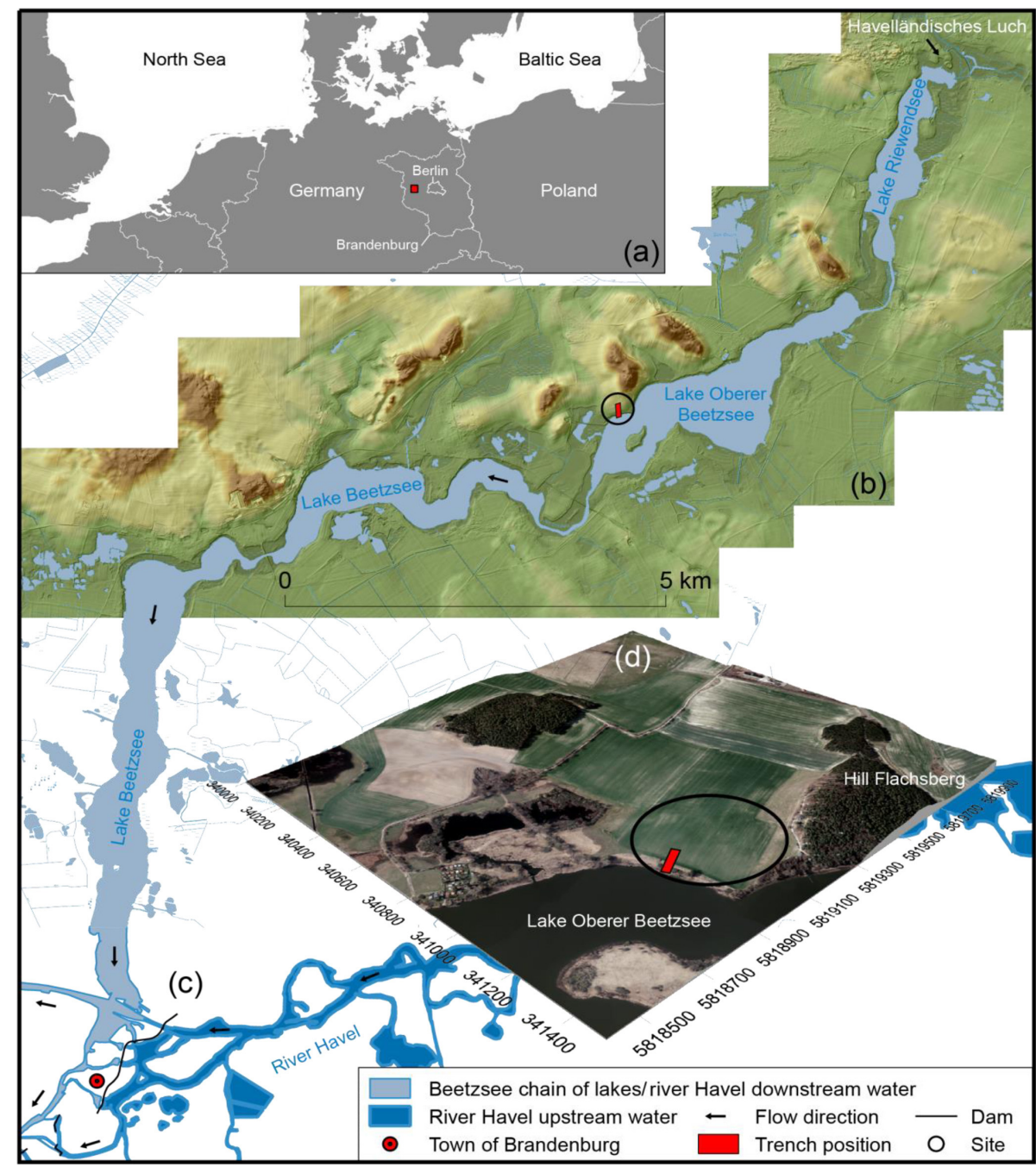

Figure 1. The Beetzsee chain of lakes in northeastern Germany (a) with a floodplain and moraine landscape encompassing it (b). The lakes drain into the river Havel at the town of Brandenburg (c). Within the town, the river Havel is divided into an upper and lower water level due to a mill dam system. They are referred to as the upstream and downstream water (c). The position of the trench at the shore of the lake Oberer Beetzsee in a slightly elevated terrain model with view to the northwest is shown in panel (d).

tends over more than $30 \mathrm{~km}$ from the wetland area Havelländisches Luch in the north to the town of Brandenburg in the south, where it drains into the river Havel (Fig. 1b, c). The chain is thus part of the lowland and floodplain landscape of the river Havel. On the northern and northwestern banks, the lowlands merge into an undulating, partly hilly, moraine landscape (Lippstreu, 2010). Within this transitional area, the site of Gortz extends from the southwest slope of the Flachsberg hill to the shore of the lake Oberer Beetzsee (Fig. 1d). In the riparian zone, colluvial deposits resulting from different settlement phases are interwoven with lacustrine deposits, both of which lie above boulder clay and gravelly sands. The most common soils around the lake chain are Brunic Arenosols, which also occur as Brunic, Endogleyic Arenosols or Cutanic Luvisols (Abrubtic, Arenic). In the riparian zone, the geological subsoil is mostly formed by Hemic Histosols (Eutric, Drainic) and Mollic Gleysols (Arenic) (LBGR, 2018).

Archaeological evidence of anthropogenic activities in the region can be found from the Mesolithic Period (9600$5300 \mathrm{BCE}$ ) onwards and for the entire Holocene (BLDAM, 2019). Based on the available sources of information, the study focuses primarily on the period of the last 1000 years. A particular focus is on the period from the late 11th century to the early 13 th century CE. In this period the areas east of the river Elbe were strongly influenced by the colonization of land, which was organized by German regional rulers and supported by the Christian clergy. During this process, from the mid-12th century CE, German settlers were brought into the area, which had previously been inhabited by Slavic people. For the Slavs this meant the end of their political independence (Brather, 2001). 
In archaeological features, the colonization of the Slavic region is highlighted by a slow transition to a new type of ceramic (Brather, 2001). Belt decorations are typical of ceramics from the Late Slavic Period. The Late Slavic Period roughly covers the 11th and 12th centuries CE for the area east of the river Elbe (Brather, 2001). From the middle of the 12th century the German settlement took place, which is also called the Early German Period. This was accompanied by a soft, blue-grey earthenware, which was already being replaced by the higher-quality hard grey earthenware as early as 1200 CE (Mangelsdorf, 1994b). The introduction of new technologies, such as the heavy plough, or the founding of new towns, led to far-reaching changes on the economic and infrastructural level (Brather, 2001). Large-scale agricultural cultivation, damming and hydro-melioration projects began to influence the water level of the middle and lower Havel, which led to lasting changes that are still visible in the landscape today (Kaiser et al., 2018). This raises the question of the extent to which the Gortz site was affected by these changes.

In Slavic times, the banks of the Beetzsee chain of lakes was one of the most densely settled areas in the Havelland area, with the large settlement chamber of Brandenburg in the south and Riewend in the northeast (Sasse, 1987). The Gortz site is situated half way up in an elevated position, from where there is a wide view over the lakes. Due to its surface finds, the site is referred to in the literature as a medieval deserted village, which must have existed at least from the Late Slavic to the Early German Period (Krenzlin, 1956; Mangelsdorf 1994a). Today there is an extensive field in this location. The village of Gortz, which still exists today, was founded about $2 \mathrm{~km}$ away in a higher location, although the tract of land on which the site sits has retained the name "Die alten Dörfer" (the old villages) (Krenzlin, 1956). These field names like "Dorfstelle", "Wüste Dorfstätte" and "altes Dorf" (village place, desert village site and old village) indicate that the original location was abandoned in the Late Slavic/Early German transition period (Krenzlin, 1956).

The archaeological investigations, carried out by Professor Thomas Schenk from the University of Applied Sciences Berlin since 2014, show a multi-period settlement history, which stretches from the Neolithic to the High Middle Ages. This is reflected in the numerous finds, some of which are unique in the Brandenburg region. The settlement character and the special significance of the site are reflected in the numerous metal finds covering a broad spectrum, as well as a large number of recognizable pits and hearths (Schenk, 2018).

\section{Methods}

Since 2014 the University of Applied Sciences Berlin has been researching the landscape archaeology of the region around the Beetzsee chain of lakes. This includes geophysi-

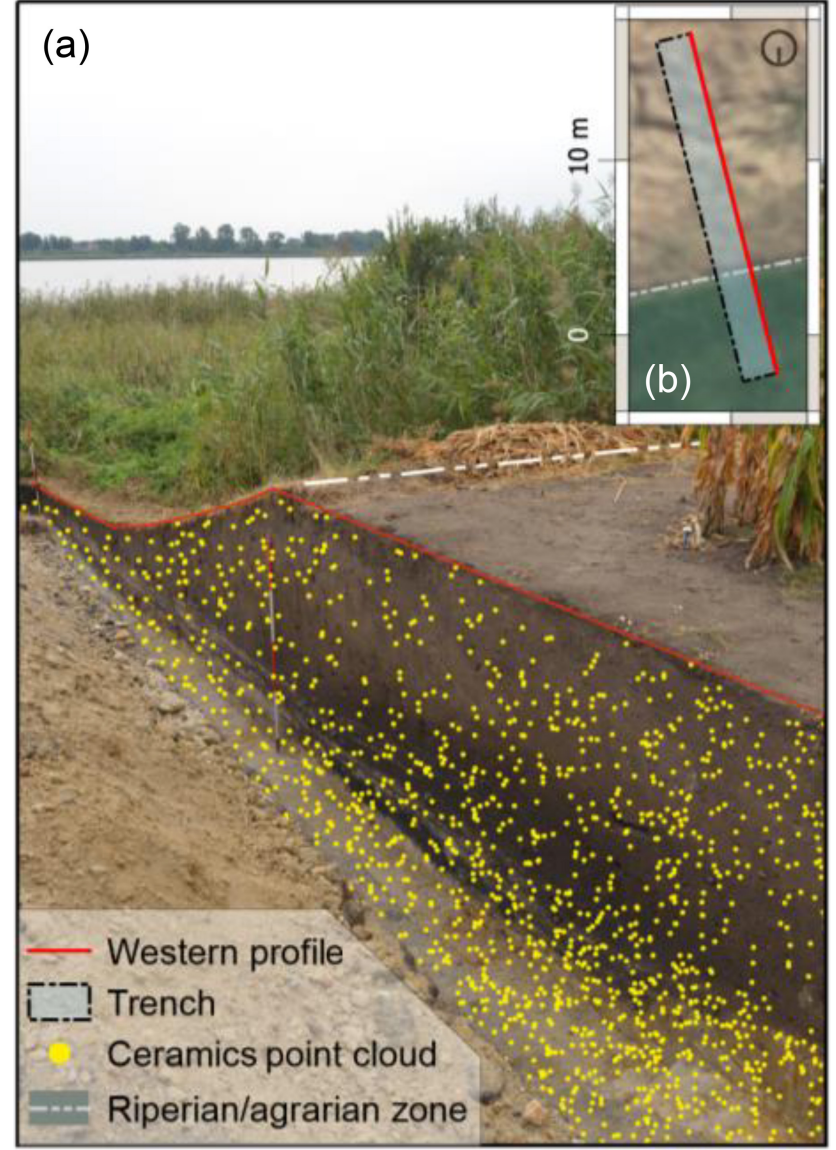

Figure 2. Photo of the investigated trench which extends from the foot of the slope into the riparian zone of Oberer Beetzsee with view to the south. The point cloud represents the ceramics recorded tachymetrically during the excavation, which was later projected onto the western profile of the trench during the post-excavation evaluation (a). The position of the western profile in the plan view (plan was oriented to the south), which served as the visualization layer for the point cloud, is shown in panel (b).

cal prospection, field-walking surveys, sieving, and counting material from test pits and excavations. The Gortz site has been a special focus, due to its diachronic settlement history, its location and the acute threat posed by its agricultural use. In order to investigate the colluvial deposits which have accumulated on the foot of the slope, a $20 \mathrm{~m}$ long trench was cut following the direction of the slope, from the foot of the slope down to the riparian zone of the lake Beetzsee (Figs. 1d, 2). The trench was dug down to the $\mathrm{C}$ horizon. This resulted in two longitudinal profiles following the direction of the slope with a length of $20 \mathrm{~m}$ and a depth of over $2 \mathrm{~m}$. The longitudinal profiles show the stratigraphy of the colluvial deposits. Only the western profile was used for the post-excavation evaluation (Fig. 2a, b).

In order to date the colluvial deposits, not only the finds from the profile wall but all finds from the trench should be 


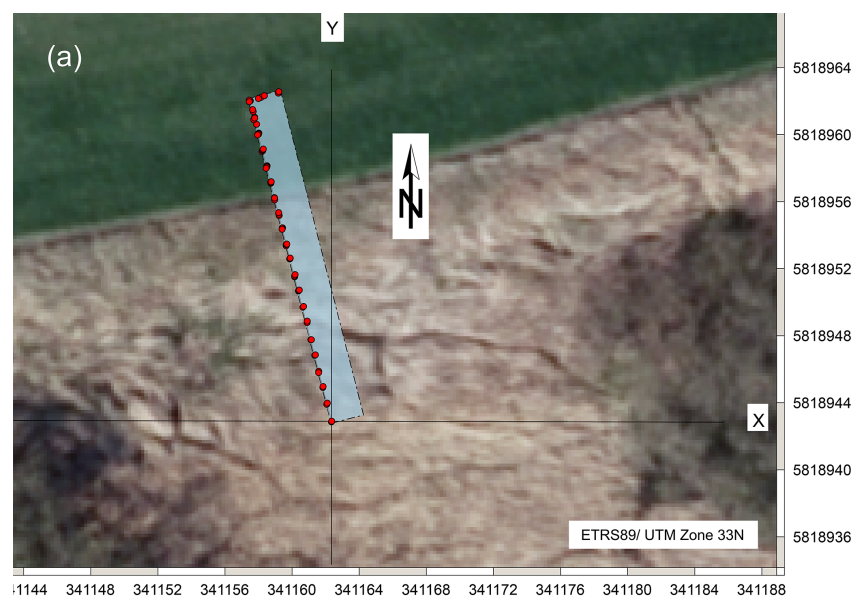

(b)

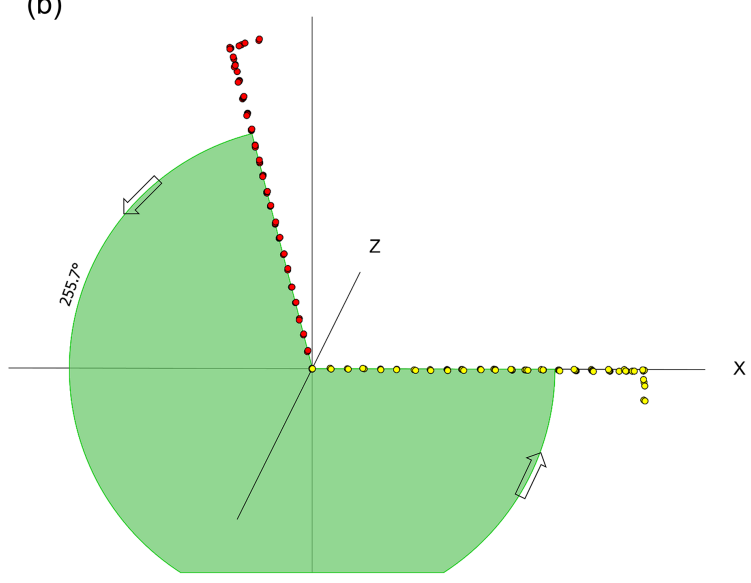

(1)

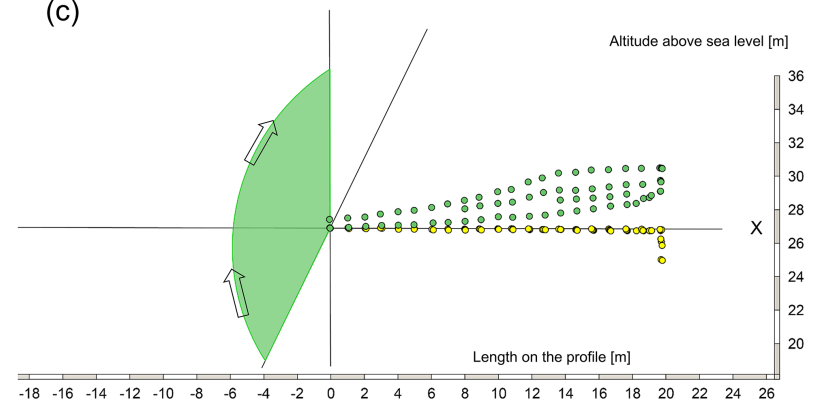

Figure 3. Rotation of the point cloud by matrix multiplication using the photogrammetry points of the western longitudinal profile as an example.

used $^{1}$. For this reason, the position of every find was recorded

\footnotetext{
${ }^{1}$ The background is that finds within colluvial deposits have often been displaced and therefore have less significance regarding the exact timing and circumstances (archaeological features) of their deposition. However, with a greater number of finds, even if they
}

using a total station (Fig. 2a). During the post-excavation evaluation, all identifiable ceramic fragments were archaeologically dated.

The visualization of the western longitudinal profile and the subsequent dating of the layers was achieved using QGIS 2.18.3. In order to enable the visualization in a GIS, the first step was to project the tachymetrically recorded point cloud of all finds of the trench onto the profile wall (Fig. 2a). In a second step, the profile was tilted from the profile view to plan view. A matrix multiplication in Excel served as an aid for this process, in which points with $x y z$ coordinates can be rotated around the three spatial axes $(X, Y, Z)$ at will (Kühnlein, 2019). This manipulation of the coordinates becomes necessary if the profile is not aligned with one of the cardinal axes (north-south $=Y$, west-east $=X$ ) shown in Fig. 3a. Prerequisites are that

A: the angle of deviation from one of the cardinal axes is known and

B: the complete dataset of a trench is summarized in one Excel table.

For the projection onto the profile, the point cloud was rotated around the $Z$ axis until it had an east-west orientation. The points thus receive a new artificial easting, which lies exactly on the $X$ axis (Fig. 3b). Without this step, the finds could only be displayed distorted in GIS. In a second step, the tilting into the plan view took place by defining the height values as the new northing (Fig. 3c). The easting coordinates are then reset to an artificial zero point so that profile metres (metres on the profile) can be displayed on the $X$ axis (Fig. 3c). In order to generate a visualization layer, the western profile following the direction of the slope was recorded photogrammetrically and the photos were georeferenced in QGIS. This method of rotating coordinates allows an unlimited number of profiles with their real height values to be displayed side by side and compared within one project file. The layers were then redrawn and dated based on the ceramic. Many of the thin layers proved particularly difficult to reliably date. Where finds were measured further away from the profile wall, they could be considered as belonging to any number of adjacent layers. Therefore, the 58 recorded strata were combined, using a pedological and sedimentological approach, into five phases of anthropogenic activity (Fig. 4).

\section{Results and discussions}

The elevation heights refer to the German Main Elevation Network (DHHN92) and are given here as metres above sea level (a.s.l.). The easting coordinates are given here as metres on the profile (o.t.p.). Of the approximately $1600 \mathrm{di}-$ agnostic fragments, about half could be dated (Reichel and

are potentially predominantly relocated, a more reliable dating of a layer can be made. 


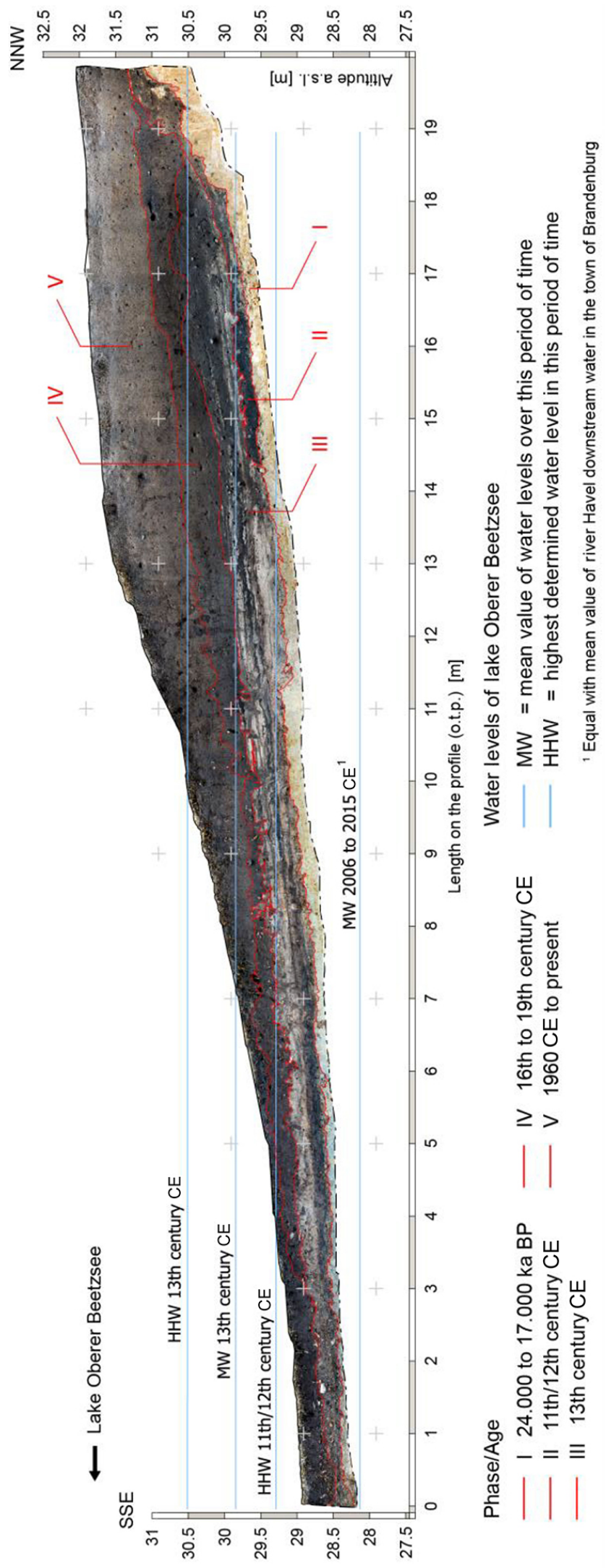

Figure 4. Photogrammetry of the western profile following the direction of the slope. The trench extends into the riparian zone of Oberer Beetzsee. The five phases were combined, using a pedological-sedimentological approach, and dated via the diagnostic ceramics of the entire trench. The dating allowed historical water levels to be determined for the periods of the 11th/12th and 13th centuries. 
Schenk, 2019). This archaeological identification of ceramic fragments formed the basis for the dating of the different phases. In cases where bioturbation could be ruled out, the most recent ceramics give the terminus post quem for the deposition of a layer (Bork et al., 1998). Phase I contains no ceramics and corresponds to the $\mathrm{C}$ horizon consisting of boulder clay and gravelly sands. Between 11.5 and 18 m o.t.p., the sequence of layers is strikingly even and straight. Gravelly sands dominate here. From 18 to 20 m o.t.p., the sequence of layers is reminiscent of a staircase that, in several steps, changes the height level by more than $1 \mathrm{~m}$. This part of phase 1 consists of boulder clay. The transition to phase II, which lies above, is sharply defined. Characteristic features of soil formation are missing. The straight, even upper edge of the $\mathrm{C}$ horizon can be interpreted as a result of ground levelling and the steps as remains of clay quarrying. The latter in particular demonstrates an anthropogenic intervention here (Fig. 4).

Phase II can be dated to the 11th/12th century CE on the basis of $42 \%$ of all ceramic sherds from this phase being Late Slavic (Reichel and Schenk, 2019). Two fragments from the German Middle Ages and a sherd from the Early Modern Period (1500-1700 CE) (Verband der Landesarchäologen, 2014) were probably introduced to these layers by strong bioturbation. The only stratum from the entire profile that can be interpreted as an in situ culture layer, due to the presence of lenses of ash and a high proportion of charcoal pieces, lies directly on the straightened $\mathrm{C}$ horizon between 14 and 17 m o.t.p. (Fig. 4). The absence of colluvial deposits, which are older than Slavic ones, is conspicuous, since much older settlement phases are documented on the site, in particular from the Early Bronze Age (2100-1500 BCE), the Roman Period (9 BCE-375 CE) and the Migration Period (375565 CE) (Verband der Landesarchäologen, 2014). All older colluvial deposits were obviously removed in the course of clay quarrying. Therefore, the in situ layer can be used for dating the clay quarrying and ground levelling into the Late Slavic Period.

On the side that borders the lake, the culture layer is cut possibly by wave erosion. There are several thin layers of light lacustrine sand running up to this stratum and covering it. Furthermore, a series of holes filled with lacustrine sands can be seen impressed into the culture layer. These holes can be interpreted as cattle hoof prints and delineate the shoreline during the Late Slavic Period in this area. At 11 m o.t.p., the straightened $\mathrm{C}$ horizon is interrupted by a $0.2 \mathrm{~m}$ high sill (Fig. 4). Here the blue-grey earthenware of the German Middle Ages appears in large numbers. The sill obviously marks the edge of the riparian zone that had been levelled. In the $11 \mathrm{th} / 12$ th century CE, the lake level must have been below this sill, suggesting a height of $29.4 \mathrm{~m}$ a.s. $1 . \pm 0.2 \mathrm{~m}$. Otherwise, no culture layer interspersed with ash lenses could have formed and been preserved between 14 and 17 mo.t.p. (Fig. 4).
Phase III is dominated by Slavic ceramics with $35 \%$ of all ceramic sherds from this phase. Blue-grey earthenware is represented by $7 \%$ of all ceramic sherds from this phase and allows the phase to be dated to the 13th century CE (Reichel and Schenk, 2019). The colluvial deposits in phase III between 16 and 19 mo.t.p. can be interpreted as Slavic. Strong indicators are the high humus content when compared to the other colluvial deposits of the profile and the charcoal particles, which cause a darker-coloured sediment (Schatz, 2011).

The hydrochloric acid test $(10 \% \mathrm{HCl})$ showed a carbonate content of $>10 \%$. Thus, the colluvium is rich in carbonates (Ad-hoc-AG Boden, 2005). A high calcium carbonate content also indicates significant, if partial, erosion on the upper slope. This suggests intensive settlement activity in this phase. Due to finds of the commonly associated grey earthenware and Pingsdorfer Ware in other trenches of the site, it is likely that the German settlement started in the late 12th or early 13th century CE. So far no finds can be classified as dating back to the 14th and 15th centuries CE, probably because the village had already been relocated during the 13th century CE. However, the colluvial deposits indicate that the German settlement probably existed for less than a hundred years.

The reason for the abandonment of the settlement of Gortz remains unknown. However, erosion processes could have played a role, which is indicated by the partially high carbonate content in phase III. Between 1150 and $1250 \mathrm{CE}$, the colonization of the Havelland area led to an extensive settlement and restructuring of the landscape, the like of which had never been seen before. In the sequel, many newly founded settlements in the Havelland area were abandoned from the turn of the 12th to 13th centuries CE. Taking into account the fact that the settlers did not know the terrain and the soils, it is likely that in many cases they became victims of erosion processes they caused and had to give up the site (Mangelsdorf, 1994a).

In phase III, on the side that borders the lake, between 8 and 17 mo.t.p., there is a horizon of interlocking dark colluvial deposits and lighter-coloured lacustrine sediments (Figs. 4 and 5). Incorporation of swirled dark humus material within the entire interlocking horizon indicates that sedimentation took place in an area of slightly moving standing water. Thus, the interlocking horizon can be interpreted as a riparian zone. Each of the thin, light-coloured layers was formed during a flooding event, whereby the deposition may have occurred at short intervals. Straight above the aforementioned sill (Fig. 4, 11 mo.t.p) blue-grey earthenware of the German Middle Ages appears in large numbers. Thus, the interlocking horizon can be clearly dated to the 13th century $\mathrm{CE}$ and is therefore part of phase III. The flood events indicate rising water levels during this period. The interlocking horizon reaches up to a height of at least $29.8 \mathrm{~m}$ a.s.l. (Fig. 4). Evidently, in the 13th century CE, the level of Oberer Beetzsee rose to this height. However, isolated flooding events 


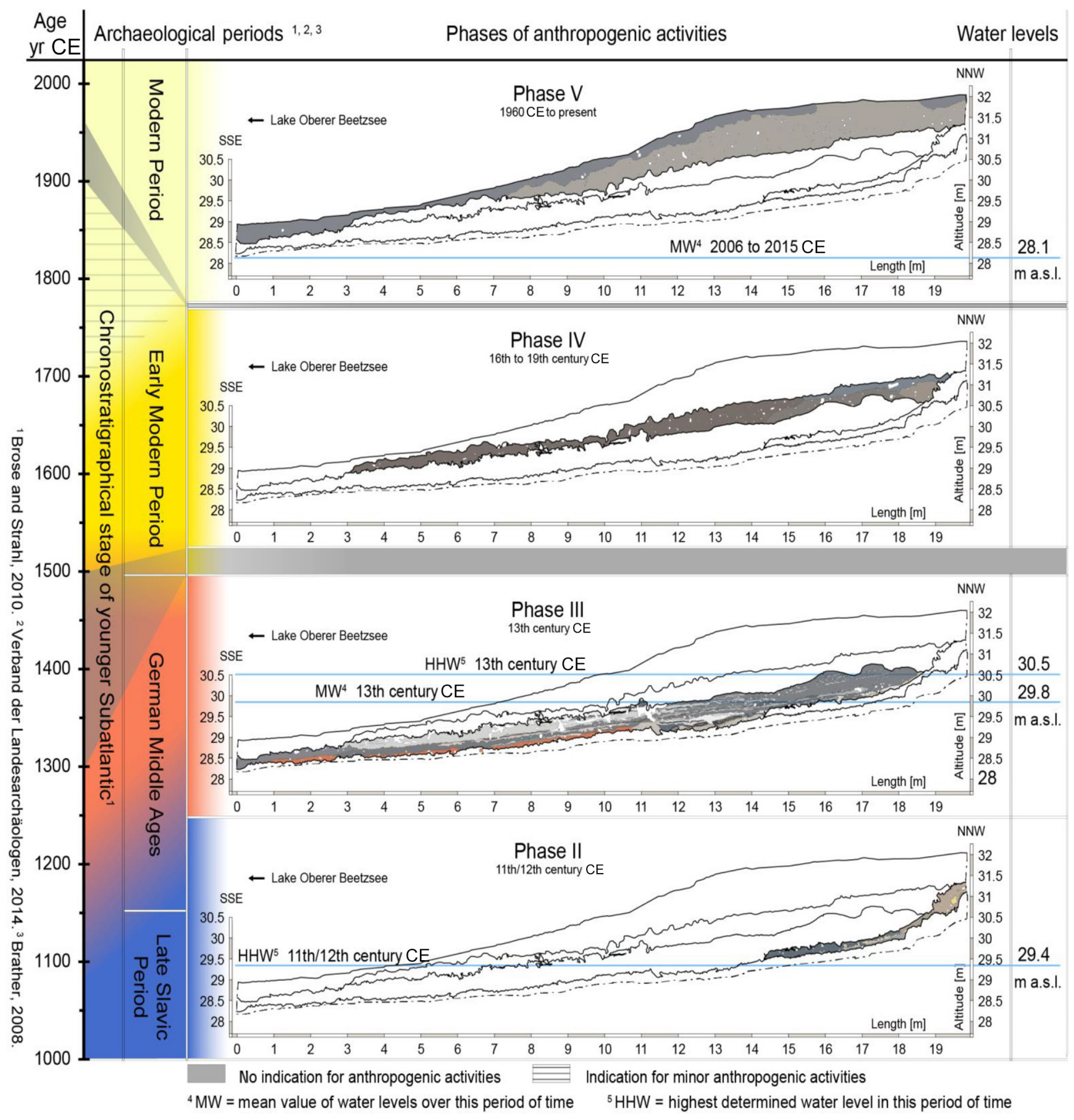

Figure 5. Development of the anthropogenic activities at the site Gortz from the Late Slavic Period to the present day, and the associated development of water level changes of the lake Beetzsee.

during the 13th century $\mathrm{CE}$ can be recorded up to a height of $30.5 \mathrm{~m}$ a.s.l. (Fig. 4 ).

This increase has regional significance, as the Beetzsee chain of lakes is connected to the lower Havel river (Fig. 1). Historical sources indicate that water levels in the river Havel region rose by an average of 1-2 $\mathrm{m}$ due to medieval mill dams (Driescher, 2003). The Beetzsee chain of lakes drains into the river Havel at the town of Brandenburg. Since the first half of the 13th century CE the river Havel has been divided into an upper and lower water level by a mill dam system (Müller, 2009). They are referred to in this study as the upstream and downstream water. The most recent study assumes that the dam system caused a water level rise of $1.5 \mathrm{~m}$ in the upstream water (Kaiser et al., 2018). However, the Beetzsee chain of 
lakes drains into the river Havel downstream from the dam system (Fig. 1) The dams associated with medieval mills may not have played a direct role in the rise of Beetzsee, whereas fish weirs could be responsible for rising water levels (Kaiser et al., 2012). Nowadays the downstream water level values in the town of Brandenburg are also valid for the Beetzsee chain of lakes. Between 2006 and 2015, the mean value of the downstream water level was at $28.13 \mathrm{~m}$ a.s.l. (WSA Brandenburg, 2015). Thus the water level of Oberer Beetzsee in the 13th century CE was $1.6 \mathrm{~m}$ above the present-day level.

Phase IV features the highest number of archaeological finds in the whole trench (Reichel and Schenk, 2019). Yellow-glazed and occasionally also brick-red earthenware date the colluvia to the $16 \mathrm{th} / 17$ th century $\mathrm{CE}$ at the earliest. This was a time when the settlement had already been abandoned for about 300 years and the site was being used agriculturally. A later origin of phase IV is also conceivable, provided that in the 18 th/19th century CE only little domestic waste had reached the fields (Fig. 5). The transition between the foot of the slope and the shore area was until this period less steep than today (Schenk, 2018).

Phase V contains a balanced spectrum of ceramics from Bronze Age to current times. Thus this is the only phase with recent ceramics (Reichel and Schenk, 2019). In addition, associated finds, such as plastic bands and the light colour of the substrate, typical of recent deposits, also suggest a Modern Period colluvia (Fig. 5). Its deposition can be associated with agro-structural measures that had a strong influence on landscape development from the 1960s to the 1980s. Land consolidation and collectivization led to destructions of important soil-protecting landscape structures (Bork et al., 1998). These measures have probably also been implemented in Gortz by the local agricultural producer cooperative. Within $>70$ years a colluvial deposit of $1 \mathrm{~m}$ thickness has formed. This impressively demonstrates the endangerment of the archaeological site by modern agriculture.

\section{Conclusions}

Consistent tachymetric mapping of the finds of a trench and their projection onto one of the longitudinal profiles within a GIS environment, in combination with a sedimentologicalpedological approach to combine neighbouring layers into phases, led to new insights into the settlement and landscape development of the studied site and its surroundings. The advantages of our approach are an unambiguous spatial allocation of the finds. In addition, not only the ceramic embedded in the profile wall but also the datable ceramic from the entire trench can be used to date the phases. The larger number of ceramic fragments that can be used for dating can provide a more reliable determination of the age of the phases.

On the basis of the recovered ceramics, it was feasible to approximate the sedimentation time of the differing colluvial phases. The timing of the sedimentation of the shoreline deposits in the interlocking horizon could thus be dated indirectly.

From the Late Slavic Period onwards, phases with settlement processes as well as phases with anthropogenic resting can be observed at the site. Especially in the Late Slavic settlement phase, it can be proved that intensive activities in the shore area such as the straightening of the bank and clay quarrying took place. Cattle hoof prints show the course of the riparian zone at that time. The interlocking horizon indicates a change in the shoreline from the 11th/12th to 13 th centuries CE. During this time, the lake water level rose from $<29.4 \mathrm{~m}$ a.s.1. to approximately $29.8 \mathrm{~m}$ a.s.1. Thus the water level of Oberer Beetzsee in the 13th century CE was $1.6 \mathrm{~m}$ above the present-day level.

Up to now no colluvial deposits could be assigned to the 14th and 15th centuries $\mathrm{CE}$, so that a resting phase on the site can be assumed (Fig. 5). This is probably because the settlement had already been deserted in the 13th century CE.

The modern colluvial deposit of $1 \mathrm{~m}$ thickness indicates an acute endangerment of the archaeological site. The cultivation of maize, which has been practised here for years, is also responsible for the high erosion rates. But also the cultivation of asparagus, which is widespread in the region, would entail far-reaching soil interventions, which would lead to the irreparable destruction of archaeological features in a short time. It is clear that a continuation of agricultural use in its present form will inevitably mean the loss of remaining archaeological features in the coming decades.

Data availability. The data presented here are available online at https://opus4.kobv.de/opus4-htw/frontdoor/index/index/docId/363 (last access: 7 July 2019) (Reichel and Schenk, 2019).

Supplement. The supplement related to this article is available online at: https://doi.org/10.5194/egqsj-68-107-2019-supplement.

Author contributions. Fieldwork was performed by JR and SFH under the project supervision of TSche. Pedological and sedimentological expertise came from TScha; archaeological dating of ceramics was done by TSche. JR and SFH prepared the manuscript and JR the figures.

Competing interests. The authors declare that they have no conflict of interest.

Special issue statement. This article is part of the special issue "Geoarchaeology and past human—environment interactions". It is not associated with a conference. 
Acknowledgements. We thank the Ministry of Science, Research and Culture Brandenburg for funding the 2016 Gortz 1 campaign partly.

We thank an anonymous reviewer as well as the guest editor, Hans von Suchodoletz, who made very helpful comments on an earlier version of the manuscript.

We would like to thank Fiona Vernon, who contributed very helpful comments regarding the English translation.

Stefan Dalitz (Heritage Conservation, Municipal Office Brandenburg/Havel) and his family, Alessandra Mancinelli, Diana Catalina Acosta Parsons, Andrey Jostes and Leroy Fischer (all University of Applied Sciences Berlin), are acknowledged for their participation in field work during the 2016 Gortz 1 campaign.

\section{References}

Ad-hoc-Arbeitsgemeinschaft Boden: Bodenkundliche Kartieranleitung, 5, edited by: Bundesanstalt für Geowissenschaften und Rohstoffe, Staatliche Geologische Dienste der Bundesrepublik Deutschland, Schweizerbart, Hannover, 2005.

BLDAM, Brandenburg Department of Cultural Heritage and Archaeological State Museum: Fundplaetze FZK (Fundart/Zeitstellung/Kultur), Wünsdorf, 2019.

Bork, H. R., Bork, H., Dalchow, C., Faust, B., Piorr, H. P., and Schatz, T.: Landschaftsentwicklung in Mitteleuropa: Wirkung des Menschen auf Landschaften, 1, Gotha, Stuttgart, Germany, 1998.

Brather, S.: Archäologie der westlichen Slawen: Siedlung, Wirtschaft und Gesellschaft im früh- und hochmittelalterlichen Ostmitteleuropa, 2, Ergänzungsbände zum Reallexikon der Germanischen Altertumskunde, 61, edited by: Beck, H., Geuenich, D., and Steuer, H., Walter de Gruyter, Berlin, New York, 2008.

Brose, F. and Strahl, J.: Die Gliederung des Holozäns im Land Brandenburg, The Brandenburg State Office for Mining, Geology and Raw Materials, Germany, 135, available at: https:// www.geobasis-bb.de/geodaten/lbgr/4_geoatlas.htm (last access: 7 July 2019), 2010.

Driescher, E.: Veränderungen an Gewässern Brandenburgs in historischer Zeit, Studien und Tagungsberichte, 47, Potsdam Landesumweltamt, Potsdam, 2003.

Kaiser, K., Günther, K., Lorenz, S., Merz, B., Bens, O., and Hüttl, R., F.: Historische Veränderungen des Wasserhaushalts und der Wassernutzung in Nordostdeutschland, in: Historische Perspektiven auf Wasserhaushalt und Wassernutzung in Mitteleuropa, edited by: Kaiser, K., Merz, B., Bens, O., and Hüttl, R. F., Waxmann Verlag, Münster, Germany, 73-102, 2012.

Kaiser, K., Keller, N., Brande, A., Dalitz, S., Hensel, N., Heußner, K.-U., Kappler, C., Michas, U., Müller, J., Schwalbe, G., Weiße, R., and Bens, O.: A large-scale medieval dam-lake cascade in central Europe: water level dynamics of the Havel River, BerlinBrandenburg region, Germany, Geoarchaeology, 33, 237-259, https://doi.org/10.1002/gea.21649, 2018.

Kühnlein, K.: Punkte mit xyz-Koordinaten um drei Achsen drehen, available at: http://www.excelformeln.de/tips.html?welcher= (last access: 7 July 2019), 53, 2019.

Krenzlin, A.: Deutsche und slawische Siedlungen im inneren Havelland, Ausgrabungen und Funde: Nachrichtenblatt der Landesarchäologie, 1, 174-185, 1956.
LBGR: Bodengeologische Übersichtskarte im Maßstab 1:300 000 (BÜK 300), The Brandenburg State Office for Mining, Geology and Raw Materials, Germany, available at: http://www.geo. brandenburg.de/lbgr/bergbau (last access: 7 July 2019), 2018.

Lippstreu, L.: Landschaftsgenese, The Brandenburg State Office for Mining, Geology and Raw Materials, Germany, 157, available at: https://www.geobasis-bb.de/geodaten/lbgr/4_geoatlas. htm (last access: 7 July 2019), 2010.

Lippstreu, L. and Hermsdorf, N.: Die Gliederung des Pleistozäns im Land Brandenburg, The Brandenburg State Office for Mining, Geology and Raw Materials, Germany, 134, available at: https:// www.geobasis-bb.de/geodaten/lbgr/4_geoatlas.htm (last access: 7 July 2019), 2010.

Mangelsdorf, G.: Die Ortswüstungen des Havellandes, Ein Beitrag zur historisch-archäologischen Wüstungskunde der Mark Brandenburg, Veröffentlichungen der Historischen Kommission zu Berlin, 86, edited by: Mangelsdorf, G., Walter de Gruyter, Berlin, New York, 1994a.

Mangelsdorf, G.: Untersuchungen zur Formenkunde spätmittelalterlicher Keramik im westlichen Brandenburg, Europäische Hochschulschriften, 50, edited by: Mangelsdorf, G., Peter Lang, Frankfurt/M, 1994b.

Müller, J.: Wasserbau als Infrastruktur der mittelalterlichen Planstadt: Brandenburg an der Havel, in: Mitteilungen der deutschen Gesellschaft für Archäologie des Mittelalters und der Neuzeit, 21, Untermann, M., Paderborn, 2009.

Reichel, J. and Schenk, T.: 2016_Gortz1_trench5_finds_data record, University of Applied Sciences Berlin, data set, available at: https://opus4.kobv.de/opus4-htw/frontdoor/index/index/ docId/363 (last access: 7 July 2019), 2019.

Sasse, B.: Die spätslawische und frühdeutsche Zeit, in: Das Havelland im Mittelalter: Untersuchungen zur Struktur einer ostelbischen Landschaft in slawischer und deutscher Zeit, Germania Slavica, 5, Berliner historische Studien, 13, edited by: Ribbe, W., Dunker und Humblot, Berlin, 1987.

Schatz, T.: Bodenkundlich-geoarchäologische Untersuchungen zur historischen Gewässerdynamik in der Aue der unteren Mittelelbe (Lkr. Lüchow-Dannenberg ), in: Slawen an der Elbe, edited by: Willroth, K.-W. and Schneeweiß, J., Wachholtz Verlag, Neumünster, 2011.

Schenk, T.: Südhang mit Seeblick. Mehrphasiger Siedlungsplatz am Beetzsee, Lkr. Potsdam-Mittelmark, in: Archäologie in Berlin und Brandenburg, edited by: Archaeological Society in Berlin and Brandenburg e.V. in cooperation with the Brandenburg Department of Cultural Heritage and Archaeological State Museum and Landesdenkmalamt Berlin, Theiss, Stuttgart, Germany, 8083, 2018.

Stackebrandt, W. and Lippstreu, L.: Brandenburg-Eisrandlagen in Brandenburg und ihre möglichen Verknüpfungen, The Brandenburg State Office for Mining, Geology and Raw Materials, Germany, 157, available at: https://www.geobasis-bb.de/geodaten/ lbgr/4_geoatlas.htm (last access: 7 July 2019), 2010.

Verband der Landesarchäologen: Kommission Archäologie und Informationssysteme: Zeitstrahl, available at: http://www.landesarchaeologen.de/fileadmin/ Dokumente/Dokumente_Kommissionen/Dokumente_ Archaeologie-Informationssysteme/Dokumente_AIS_Thesauri/ Zeitstrahl_V01.pdf (last access: 7 July 2019), 2014. 
WSA Brandenburg: Aktuelle Wasserstandshauptwerte, Zehnjahesreihe 2006 bis 2015 einiger Pegelstationen des WSA Brandenburg, Brandenburg Waterways and Shipping Authority, Germany, available at: http://www.wsa-brandenburg.wsv.de/service/ Wasserstaende/index.html (last access: 7 July 2019), 2015. 